\title{
Data report: a brittle (normal?) shear zone from Hole C0002P: deformation structures and their relationship with calcite veins (IODP Expedition 348, Nankai Trough accretionary prism) ${ }^{1}$
}

\author{
Ana Crespo-Blanc ${ }^{2}$
}

\section{Chapter contents}

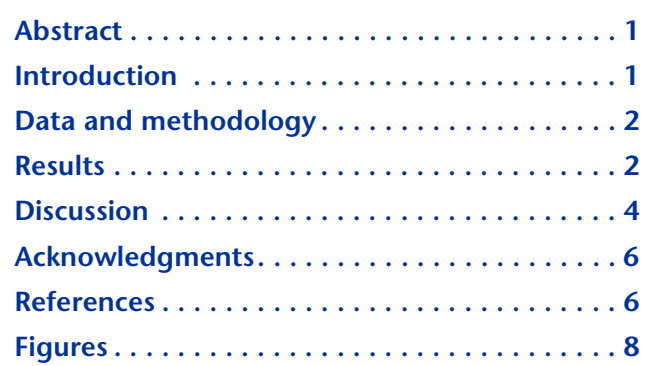

${ }^{1}$ Crespo-Blanc, A., 2017. Data report: a brittle (normal?) shear zone from Hole C0002P: deformation structures and their relationship with calcite veins (IODP Expedition 348, Nankai Trough accretionary prism). In Tobin, $\mathrm{H}_{\text {., }}$ Hirose, T., Saffer, D., Toczko, S., Maeda, L., Kubo, Y., and the Expedition 348 Scientists, Proceedings of the Integrated Ocean Drilling Program, 348: College Station, TX (Integrated Ocean Drilling Program). doi:10.2204/iodp.proc.348.205.2017

${ }^{2}$ Departamento de Geodinámica-Instituto Andaluz Ciencias de la Tierra, Facultad de Ciencias, Universidad de Granada-Consejo Superior de Investigación Científica, Fuentenueva s/n, 18071 Granada, Spain. acrespo@ugr.es

\section{Abstract}

A brittle shear zone was sampled from Hole C0002P in the Nankai accretionary prism during Integrated Ocean Drilling Program Expedition 348. Macro- and microscopic structures observed both in the core and the covered petrographic thin sections of this fault zone permit characterization of the deformation during faulting. The observed kinematic indicators are coherent with an apparent normal fault sense with respect to its present-day position. Calcite veins are restricted to the most damaged interval of the cored fault. Descriptions of the vein geometry and relationship with the cataclastic foliation present in the fault suggest that these are extension veins that opened during a crack-seal. The various generations of veins suggest that a reiterative history of brecciation and veining took place.

\section{Introduction}

During Integrated Ocean Drilling Program (IODP) Expedition 348, part of the Nankai Trough Seismogenic Zone Experiment (NanTroSEIZE) (Stage 3), the D/V Chikyu conducted riser drilling to extend an existing hole at Site C0002 (2005.5 meters below seafloor [mbsf] reached during IODP Expedition 338 [Strasser et al. 2014]) to 3058.5 mbsf (see the "Site C0002" chapter [Tobin et al., 2015]). This site is located $80 \mathrm{~km}$ southeast of the Kii Peninsula (Japan) in the Kumano forearc basin, on top of the Nankai accretionary prism (Fig. F1). The prism formed during subduction of the Philippine Sea plate to the northwest beneath the Eurasian plate. The accreted material consists of Shikoku Basin sediments deposited during the late Oligocene to late Miocene rifting and backarc spreading behind the Izu-Bonin arc system (Kobayashi et al., 1995) on the northern margin of the subducting Philippine Sea plate. The Nankai prism is actively accreting in the frontal wedge near the toe of the prism; meanwhile, the subhorizontal sediments of the Kumano forearc basin lie on top of the fold-andthrust belt of the inner accretionary prism.

Cuttings (875.5-3058.5 mbsf) and cores (2163.0-2217.5 mbsf) were collected in the upper Miocene to Pliocene turbiditic silty claystone with few intercalations of sandstone and sandy siltstone that characterize the accretionary prism lithologic units drilled during Expedition 348 (see the "Site C0002" chapter [Tobin et al., 2015]). A remarkably preserved brittle shear zone, 90 
cm long (apparent thickness), was cored around 2205 mbsf (Section 348-C0002P-5R-4, hereafter Section 5R-4). The shear zone is located in lithologic Unit V (Strasser et al., 2014; see the "Site C0002" chapter [Tobin et al., 2015]), formed of silty claystone and sandstone.

This paper describes the macro- and microscopic structures observed both in the core and in the covered petrographic thin sections of this fault zone, which show an anastomosing cataclastic foliation and the occurrence of calcite veins, restricted to the most damaged interval of the cored fault zone. The main objectives of this study were

1. To characterize the brittle deformation during faulting through the type of deformation structures, in particular in terms of kinematics, and

2. To unravel the vein opening mechanism determined from their study, with special emphasis on their geometry, internal texture, and their relationships with the deformation structures of the wall rock.

\section{Data and methodology}

Macroscopic observations on cores were made offshore during the expedition. On shore at Kochi Core Center (Japan Agency for Marine-Earth Science and Technology [JAMSTEC], Kanagawa, Japan), a slab of Section 5R-4 was solidified before thin section preparation. It was divided into three pieces, using the same places where drilling mud intruded into the core (see locations of these planes in Fig. F2A). These pieces were coated with epoxy resin and dried. Finally, they were cut parallel to the surface of the half-core and polished. Fourteen extra-large covered petrographic thin sections (around $60 \mathrm{~mm} \times 45 \mathrm{~mm}$ ) were prepared along the whole core section. These latter thin sections were studied with an optical microscope at Granada University (Spain).

It must be stressed that the description of the fault breccia includes only the structures due to tectonic deformation. The criteria for the differentiation of drilling-induced structures from tectonic ones are fully described in Keren and Kirkpatrick (2016).

\section{Results \\ Macroscopic observations}

The available photographs of the whole Section 5R-4 can be seen in Figure F2. These images correspond to the archive half photographed on board the ship and the two surfaces of the slab made for thin section preparation at Kochi Core Center. As the slab is composed of three pieces, its total length is slightly lon- ger than that of the core. Moreover, the photographs are not continuous.

The whole Section 5R-4 can be considered as an incohesive fault breccia in the sense of Sibson (1977) with more than $30 \%$ large clasts $(>2 \mathrm{~mm}$ ) in a clayrich matrix. The clasts are formed of either silty claystones and/or sandstones and their size is heterogeneous, occupying the whole core diameter $(6.4 \mathrm{~cm})$ to $<0.1 \mathrm{~cm}$. From 57 to $91 \mathrm{~cm}$ of the archive half, the clasts are smaller than those in the remainder of the fault zone (Fig. F2A). This is considered the most damaged part of the fault breccia in Section 5R-4. This is also the only part of the core where calcite veins appear (whitish tones, clearly observable around 59, 79, and $87 \mathrm{~cm}$ offset in the archive half) (see Fig. F3).

The anastomosing cataclastic foliation, whose mean orientation is indicated on the right side of Figure F2, is defined by the preferred orientation of the centimeter- to submillimeter-spaced, parallel fracture systems, which affect the silty claystone and sandstone, surrounding elongated lentil-shaped clasts. Note that the three pieces of Section 5R-4 rotated differentially; accordingly, the present-day orientation of the cataclastic foliation in the section varies from one piece to the other.

The anastomosing character of this foliation appears broadly as two families of clear or dark lines (Fig. F3A or F3B, respectively) cutting the silty claystones at an angle of around $50^{\circ}-60^{\circ}$. This foliation corresponds to microfaults. These microfaults systematically produce lengthening of the markers. For example, a domino-like structure can be seen in Figure F3B. In Figure F3A, an asymmetric clast of sandstone, $4 \mathrm{~cm}$ long, appears in the most damaged zone of the fault breccia. Its shape is consistent with the microfault kinematics, which are indicated in Figures F2 and F3.

\section{Deformation structures observed in thin sections}

The thin sections correspond to the surface of the slab shown in Figure F2C. They are located according to IODP conventional numeration, based on the measuring tape situated below Figure F3C, and are named as such. Nevertheless, the thin sections do not cover the entire specified length, as shown in Figure F3, where the exact area of the thin sections has been drawn on the selected slab surface. The thin sections are vertical, and the top of the core is indicated in each of the photographs.

The characteristic sedimentary texture of the undeformed rocks of the fault zone are shown in Figure F4. The rocks consist of silty claystones and sand- 
stones. The boundary between sandstone and finegrained silty claystone, which can be used as a marker of the deformation, is generally sharp and consists of microfaults. Sometimes, the bedding is preserved and a transitional boundary between both lithologies can be observed. Also, some elongated patches of claystones within the sandstones and/or finer grained claystones are present (mud ball, Fig. F4A-F4B). The sand grains within the sandstones are angular and embedded in sparse matrix/cement (Fig. F4C). Clasts of quartz are dominant (monocrystalline grains) and those of feldspar are abundant, whereas lithic fragments are scarce. Few fossils are preserved (Fig. F4D). A complete description of the lithology of the undeformed rocks can be found in the "Site C0002" chapter (Tobin et al., 2015).

Microfaults are the most common deformation structure observed in the fault zone thin sections. At core scale (Figs. F2, F3), the geometry of the microfaults forms lenticular structures surrounding clasts of sandstones or claystones (Fig. F5). The microfaults and the lenticular structures define the anastomosing character of the cataclastic foliation. The shear sense along this cataclastic foliation is revealed by the deflection and/or displacement of the markers, as shown in Figure F5A. In this example, with respect to the top of the core, the shear sense component is that of a normal fault (present-day position).

Within the microfault planes, the clayey minerals show a preferred orientation, highlighted under crossed nicols in Figure F6. These faults are located generally along the boundary between competent sandstones and less competent claystones, if both lithologies are present in the thin section (Fig. F7). Sometimes, deformational structures are concentrated along the vicinity of this boundary, as shown in Figure F7A-F7B, where an array of microfaults developed in the claystones. The boundary between both lithologies can also be cut by the microfaults that comprise the cataclastic foliation (Fig. F7C). In this case, the quartz grains are crushed and reduced along the microfault plane (Fig. F7D). Opaque material also concentrates along the same plane.

In the vicinity of these microfaults, drag folds can be present (Fig. F8). The drag is generally marked by the clayey material included in a previous microfault but can also be drawn by the fragments of broken fossils. In this case, observe how the drag fold, shown by the progressive alignment of the fossil fragments more marked toward the microfault, is coherent with the movement of the brownish claystone marker of Figure F8B.

Concerning the kinematics of the microfaults, it is striking to note that they systematically produce lengthening of the markers (original bedding, layer bounded by previous microfaults, layer of opaques, etc.). For example, this is very clear in Figure F9A, where an array of microfaults cut a layer of claystones intercalated between sandstones. With respect to the present-day position of the core top, as indicated in each photograph, most of the microfaults show a component of normal shear sense along their apparent dips (indicated in Figs. F5, F7, F8, F9). Finally, the frequent staircase geometry of the band of opaque minerals is coherent with both the observed microfault shear sense and the marker lengthening (Fig. F9), which in turn is seen at all scales, from core scale (Fig. F3) to microscopic scale (Figs. F5, F7, F8, F9).

\section{Calcite veins and their relationships with deformation structures observed in the fault zone}

Calcite veins appear only in the most damaged part of the cored fault zone, from 57 to $91 \mathrm{~cm}$ (archive half), which is within the $34 \mathrm{~cm}$ interval where the cataclastic foliation is particularly well developed (Fig. F3). At macroscopic scale, these veins appear as whitish ribbons (Fig. F2A, particularly around 59, 79, and $87 \mathrm{~cm}$ offset in the composite section).

Six of these ribbons are present in thin sections TS 57-64, TS 64-71, TS 71-78, and TS 78-85. The locations of these ribbons are shown in Figure F3C, and the large side of the rectangle coincides with their mean direction. The ribbons show different habits: two veins are formed of aggregates of very small calcite grains, and four of these veins appear as a swarm of veinlets composed of relatively coarse grained calcite.

\section{Veins formed of aggregates of very small calcite grains}

The aggregates of very small calcite grains are concentrated along bands subparallel to the cataclastic foliation (Fig. F10). The boundaries between wall rock and veins are generally well defined (Fig. F11A, upper part of Fig. F11B) but they can also be fuzzy, as calcite cements impregnate the wall rock in the vicinity of the vein boundary (lower part of Fig. F11B, F11D). In these veins, the calcite grain size varies from approximately 0.05 to $0.005 \mathrm{~mm}$ (e.g., Figs. F11, F12). This variation can be distributed within the whole aggregate or concentrated along bands subparallel to the cataclastic foliation (e.g., in the upper part of the vein shown in Fig. F12B, F12D).

Deformation affected the geometry of these aggregates of grains and they can show a lenticular shape, similar to the clasts composed by claystones situated 
in their vicinity (Figs. F11A, F11C, F12A, F12B). At the same time, these calcite aggregates can surround the claystone lentil-shaped clasts. They can be distributed along two families of bands that draw rhombs underlining the microfault arrays of the cataclastic foliation (Fig. F12B, F12C). The shear sense deduced from the microfaults that affected the aggregates of calcite grain shows a normal component (except Fig. F12B, in which the component of movement is neutral). This is coherent with the conjugated normal microfaults marked by the very fine grained bands in Figure F11B, F11D.

Finally, it is interesting to note that in Figure F11A another type of vein can be observed over the band of aggregates (left of the photograph, also see detail in Fig. F15A). The figure shows coarser calcite grains, which clearly indicate the presence of at least two generations of veins.

\section{Veins formed of relatively coarse grained calcite}

A swarm of veinlets make up a second type of veins (Figs. F13A, F13B, F14A, F14B). In the vicinity of these veinlets, isolated grains of calcite can also impregnate the wall rock (Fig. F13C, F13D). Within the veinlets, the calcite grains are generally coarse and elongated. The elongation is subperpendicular to the vein/wall rock boundaries and the crystals show little or no increase in width along their growth direction. The vein/wall rock boundaries are mostly sharp, although not perfectly straight, as there are some irregularities at the scale of the grain width (Figs. F14, F15, F16).

The geometry and distribution of these veinlets can vary. Very frequently, these veinlets draw a rhombic network with the same orientation as the microfault planes that surround the lentil-type claystone clasts, although a continuum can be observed from the rhombic network that mimics the cataclastic foliation (Fig. F14) up to the veinlets that cut and seal this foliation (Fig. F15). The calcite grains that form the veinlets are undeformed, as shown by their optical continuity, without undulose extinction (Fig. F14C). It must be stressed that independently of the veinlet orientation, the direction of the calcite grain elongation is subperpendicular to the vein boundaries (Fig. F14A, F14B).

Locally, some late deformation of this type of vein is shown by the domino-like structure drawn by the calcite grains (Fig. F15B) or by a microfault cutting the vein (Fig. F16A, F16B). It is worthwhile to note that the example in Figure F15 is in the vicinity of the band with very small calcite grains (lower part of Fig. F15A).
Within the veinlets are inclusion bands formed of fragments of the wall rock (Figs. F13C, F13D, F15A, F15D, F16C, F16D, F17A-F17C). These wall rock inclusion bands mostly show irregular geometry, although broadly subparallel to the veinlet boundaries. At microscopic scale, these wall rock inclusion bands are relatively wide, but in a few cases, very thin lines parallel with the vein/wall rock boundary can also be interpreted as inclusion bands (Fig. F17D, F17E).

The calcite grains are generally straight, with optical continuity (Figs. F14C, F15D, F16B, F17C, F17E). The veinlets are filled either by two palisades of grains that converge within the veins with an irregular boundary (radiator shaped according to Bons et al., 2012; Figs. F14, F15, F16, F17) or by single grains that join both wall rocks (Figs. F15C, F16C, F16D). In the case of two grain palisades, these latter single grains can be either symmetrical or asymmetrical. If symmetrical, the crystals are not in optical continuity across the vein. Consequently, they probably do not grow from a median suture line toward the walls. If they are asymmetrical, it is worth noting that this asymmetry is very high and that the shortest grains of calcite generally coincide with the presence of wall rock inclusion bands (Fig. F17A-F17C).

Rarely, the calcite grains can show a slightly curved geometry. In this case, no undulose extinction is observed (Figs. F16C, F16D, F17D, F17E). Accordingly, this geometry is due to a variation of the veinlet opening direction and not late deformation superimposed on the calcite crystallization. Finally, broadening of the calcite grains along the same vein likely indicates propagation of the vein tip (to the left in the case of the lowest vein in Fig. F16C, F16D).

\section{Discussion}

Figure F18 summarizes the deformation structures observed at both macroscopic and microscopic scale in the fault zone drilled in Hole C0002P (Section 5R4) combined with the main characteristics of the veins, in terms of size and geometry of calcite grains together with their orientation (apparent dip) with respect to the cataclastic foliation.

\section{Deformation regime and kinematics}

The deformation structures are characteristic of a brittle regime, which crushes the silty claystones with few intercalations of sandstones affected by faulting. The rock fragments are surrounded by an anastomosing cataclastic foliation formed of arrays 
of microfaults in which the clay minerals show a preferred orientation.

The microfaults systematically produce lengthening of the markers. Moreover, the shear sense along with the apparent dip of the cataclastic foliation with respect to the top of the core in both meso- (Figs. F2, F3) and microscale (see shear sense and core orientation in the thin sections; Figs. F5, F7, F8, F9, F11, F12) shows either a normal component or a neutral one (horizontal apparent dip of the microfault planes). Both criteria are coherent with an extensional regime of the fault that generated the breccia, that is, an apparent normal fault sense with respect to its present-day position (see the "Site C0002" chapter [Tobin et al., 2015]), reaching the same conclusion made during core description on the ship.

\section{Brecciation and timing of the veining}

Veins are present only in the most damaged part of the fault zone. They can be accompanied by scarce carbonate cementation, indicative of the role of this interval as a fluid path. The veins are filled by the growth of calcite, a mineral that is not the main constituent of the wall rock, neither of the lithologic unit affected by the described fault nor of any of the other units drilled along Site C0002 (Expedition 314 Scientists, 2009; Expedition 315 Scientists, 2009; Strasser et al., 2014; see the "Site C0002" chapter [Tobin et al., 2015]). Hence, two working hypotheses can be formulated for the origin of the carbon:

1. The carbonate was transported toward the fault zone from outside the drilled part of the accretionary prism, and/or

2. Organic material in the matrix of the sediments or small traces of soluble calcite (e.g., the foraminifers of Figs. F4D, F8C) supplied local calcite.

Crespo-Blanc et al. (2016) shows that the fault veins of Section 5R-4 have generally lower $\delta^{18} \mathrm{O}$ values than carbonate cements in the sedimentary matrix (up to $-8.7 \%$ o for $\delta^{18} \mathrm{O}$ Vienna Peedee belemnite). The depleted $\delta^{18} \mathrm{O}$ values are consistent with veins forming at higher temperatures than those present during formation of the matrix carbonate, favoring the first hypothesis for the origin of the carbonate.

In veins, the elongated shape of the grains broadly defines their mean opening direction. In the studied case, the calcite grain elongation shows that this opening direction is mostly subperpendicular to the veinlets, independent of their orientation. Therefore, the displacement vector of the fracture is perpendicular to the fracture plane and there was almost no shear component during opening. This is characteristic of extensional fractures, which form perpendicular to the minimum principal stress (Passchier and
Trouw, 2005; Bons et al., 2012). With respect to vertical of Section 5R-4, the mean orientation of the elongated shape of the calcite grains within the six observed veins are shown in Figure F18. The orientation of the vein planes are also shown, although it must be taken into account that these orientations are apparent. With the few available data, it is not possible to determine a mean opening direction, if there was such.

The frequent double palisade geometry of the elongated grains associated with the lack of optical continuity of the grains from one part to the other of the wall rock indicate that the growth direction of the elongated grains is most likely syntaxial (Durney and Ramsay, 1973). This type of growth is expected in the case of veins filled by minerals scarcely present in the wall rock (Passchier and Trouw, 2005). Growth takes place on a single plane with a consistent position within the vein, not only somewhere in the vein middle, but also nearer to one of the vein sides, as shown by the symmetry or asymmetry of the palisades, respectively. It is generally assumed that this plane is a fracture that is sealed by inward growth on both surfaces of that fracture (Bons and Montenari, 2005; Bons et al., 2012). Single grains bounding both wall rock sides indicate that growth can also be accomplished fully on one side.

A crack-seal mechanism during growth of the veins can be inferred from the presence of frequent inclusion bands of wall rock (Ramsay, 1980; Bons et al., 2012). Moreover, in the studied case, more than one inclusion band can appear on the sides of the veinlets, sometimes with irregular geometry. Accordingly, the successive crack plane can cut not only within the vein but also through the wall rock.

In terms of the timing relationship with the cataclastic foliation, the geometry of the calcite veins clearly shows that there are least two generations of these veins. The veins formed of aggregates of very small calcite grains are interpreted as early veins with initially larger grains, crushed during subsequent brittle deformation and associated with size reduction. This late deformation is evidenced by the lentil-type structure drawn by the aggregates of finegrained calcite or the normal faults that affect this type of vein. The other four veins, formed of relatively coarse grained calcite, can be considered broadly contemporaneous and mainly postdate the cataclastic foliation. This timing relationship is clear for the veinlets that cut and seal this foliation, but the relationships of the foliation with the veins that show a rhombic distribution of the veinlets that form them cannot be directly established. Nevertheless, as in this case, the calcite grains are elongated subperpendicular to the wall rock/vein boundary, in- 
dependent of the veinlet orientation, indicating that these are extensional veins. Moreover, it is not possible to observe any difference of habitus between the elongated calcite grains of veinlets that cut the cataclastic foliation and those of veins that follow it. As a consequence, it is suggested that their opening occurred along the already formed cataclastic foliation planes, which acted as weakness planes. In this case, the veins would mimic the cataclastic foliation distribution. Finally, some of these coarse-grained calcite veins deformed by extensional microfaults possibly formed domino-like structures.

These observations lead to proposing the following multistage evolution of the fault breccia and associated veins. The presence of the veins restricted to the fault zone shows that the fault zone acted as a fluid path. Accordingly, it is likely that opening of the extensional fracture took place due to the effect of elevated fluid pressure (hydrofracture). The carbon-rich fluids precipitated in the fracture, taking advantage of the cataclasitic foliation plane to develop. Then, as deformation proceeded, it affected the veins formed in the first stages, and new veins developed which in turn are deformed. This describes a reiterative history of brittle deformation and veining during an (apparent) extensional regime.

\section{Concluding remarks}

1. The shear zone from Hole C0002P was formed during a brittle regime, with the development of an anastomosed cataclastic foliation in silty claystone and scarce levels of sandstones.

2. The kinematic indicators observed in thin section are coherent with an apparent normal fault sense with respect to its present-day position.

3. The veins present in the most damaged part of the fault zone are extensional veins filled with calcite, probably transported from outside of the drilled part of the accretionary prism.

4. The veins are likely of syntaxial type and opened through a crack-seal mechanism.

5. Two generations of veins were observed: a first one strongly affected by brittle deformation and a second one sealing it, although this second generation is scarcely affected by extensional microfaults.

\section{Acknowledgments}

All the Expedition 348 scientists are acknowledged for fruitful discussion on the ship. The skill of the technicians at Kochi Core Center (JAMSTEC, Kanagawa, Japan) is greatly appreciated for making extra-large thin sections in an incohesive fault gouge. I thank the reviewers for their constructive re- views. This study was supported by Grants RNM-215 and 451 ("Junta de Andalucía," Spain) and CGL2013-46368-P ("Ministerio de Economía y Competitividad," Spain).

\section{References}

Bons, P.D., Elburg, M.A., and Gómez-Rivas, E., 2012. A review of the formation of tectonic veins and their microstructures. Journal of Structural Geology, 43:33-62. http://dx.doi.org/10.1016/j.jsg.2012.07.005

Bons, P.D., and Montenari, M., 2005. The formation of antitaxial calcite veins with well-developed fibres, Oppaminda Creek, South Australia. Journal of Structural Geology, 27(2):231-248. http://dx.doi.org/10.1016/ j.jsg.2004.08.009

Crespo-Blanc, A., Sample, J., Brown, K., Otsubo, M., Yamamoto, Y., and the IODP Expedition 348 Scientific Team, 2016. A brittle (normal?) shear zone cored in Site C0002 of Nankai Trough Seismogenic Zone Experiment (IODP Expedition 348). Geophysical Research Abstracts, 18:EGU2016-12070. http://meetingorganizer.copernicus.org/EGU2016/EGU2016-12070.pdf

Durney, D.W., and Ramsay, J.G., 1973. Incremental strains measured by syntectonic crystal growth. In De Jong, K.A., and Scholten, R. (Eds.), Gravity and Tectonics: New York (Wiley), 67-96.

Expedition 314 Scientists, 2009. Expedition 314 Site C0002. In Kinoshita, M., Tobin, H., Ashi, J., Kimura, G., Lallemant, S., Screaton, E.J., Curewitz, D., Masago, H., Moe, K.T., and the Expedition 314/315/316 Scientists, Proceedings of the Integrated Ocean Drilling Program, 314/ 315/316: Washington, DC (Integrated Ocean Drilling Program Management International, Inc.). http:// dx.doi.org/10.2204/iodp.proc.314315316.114.2009

Expedition 315 Scientists, 2009. Expedition 315 Site C0002. In Kinoshita, M., Tobin, H., Ashi, J., Kimura, G., Lallemant, S., Screaton, E.J., Curewitz, D., Masago, H., Moe, K.T., and the Expedition 314/315/316 Scientists, Proceedings of the Integrated Ocean Drilling Program, 314/ 315/316: Washington, DC (Integrated Ocean Drilling Program Management International, Inc.). http:// dx.doi.org/10.2204/iodp.proc.314315316.124.2009

Heki, K., 2007. Secular, transient, and seasonal crustal movements in Japan from a dense GPS array: implication for plate dynamics in convergent boundaries. In Dixon, T.H., and Moore, J.C. (Eds.), The Seismogenic Zone of Subduction Thrust Faults: New York (Columbia Univ. Press), 512-539.

Keren, T.T., and Kirkpatrick, J.D., 2016. Data report: tectonic and induced structures in the JFAST core. In Chester, F.M., Mori, J., Eguchi, N., Toczko, S., and the Expedition 343/343T Scientists, Proceedings of the Integrated Ocean Drilling Program, 343/343T: Tokyo (Integrated Ocean Drilling Program Management International, Inc.). http://dx.doi.org/10.2204/ iodp.proc.343343T.204.2016

Kobayashi, K., Kasuga, S., and Okino, K., 1995. Shikoku Basin and its margins. In Taylor, B. (Ed.), Backarc Basins: 
Tectonics and Magmatism: New York (Plenum), 381-405. http://dx.doi.org/10.1007/978-1-4615-1843-3_10

Moore, G.F., Boston, B.B., Strasser, M., Underwood, M.B., and Ratliff, R.A., 2015. Evolution of tectono-sedimentary systems in the Kumano Basin, Nankai Trough forearc. Marine and Petroleum Geology, 67:604-616. http://dx.doi.org/10.1016/j.marpetgeo.2015.05.032

Passchier, C.W., and Trouw, R.A.J., 2005. Microtectonics (2nd edition): Berlin (Springer).

Ramsay, J.G., 1980. The crack-seal mechanism of rock deformation. Nature, 284(5752):135-139. http:// dx.doi.org/10.1038/284135a0

Seno, T., Stein, S., and Gripp, A.E., 1993. A model for the motion of the Philippine Sea plate consistent with NUVEL-1 and geological data. Journal of Geophysical Research: Solid Earth, 98(B10):17941-17948. http:// dx.doi.org/10.1029/93JB00782

Sibson, R.H., 1977. Fault rocks and fault mechanisms. Journal of the Geological Society (London, United Kingdom), 133:191-214. http://dx.doi.org/10.1144/ gsjgs.133.3.0191

Strasser, M., Dugan, B., Kanagawa, K., Moore, G.F., Toczko, S., Maeda, L., Kido, Y., Moe, K.T., Sanada, Y., Esteban, L., Fabbri, O., Geersen, J., Hammerschmidt, S., Hayashi, H., Heirman, K., Hüpers, A., Jurado Rodriguez, M.J., Kameo, K., Kanamatsu, T., Kitajima, H., Masuda, H., Milliken, K., Mishra, R., Motoyama, I., Olcott, K., Oohashi, K., Pickering, K.T., Ramirez, S.G., Rashid, H., Sawyer, D.,
Schleicher, A., Shan, Y., Skarbek, R., Song, I., Takeshita, T., Toki, T., Tudge, J., Webb, S., Wilson, D.J., Wu, H.-Y., and Yamaguchi, A., 2014. Site C0002. In Strasser, M., Dugan, B., Kanagawa, K., Moore, G.F., Toczko, S., Maeda, L., and the Expedition 338 Scientists, Proceedings of the Integrated Ocean Drilling Program, 338: Yokohama (Integrated Ocean Drilling Program). http:// dx.doi.org/10.2204/iodp.proc.338.103.2014

Tobin, H., Hirose, T., Saffer, D., Toczko, S., Maeda, L., Kubo, Y., Boston, B., Broderick, A., Brown, K., Crespo-Blanc, A., Even, E., Fuchida, S., Fukuchi, R., Hammerschmidt, S., Henry, P., Josh, M., Jurado, M.J., Kitajima, H., Kitamura, M., Maia, A., Otsubo, M., Sample, J., Schleicher, A., Sone, H., Song, C., Valdez, R., Yamamoto, Y., Yang, K., Sanada, Y., Kido, Y., and Hamada, Y., 2015. Site C0002. In Tobin, H., Hirose, T., Saffer, D., Toczko, S., Maeda, L., Kubo, Y., and the Expedition 348 Scientists, Proceedings of the Integrated Ocean Drilling Program, 348: College Station, TX (Integrated Ocean Drilling Program). http://dx.doi.org/10.2204/

iodp.proc.348.103.2015

Initial receipt: 29 September 2016

Acceptance: 3 February 2017

Publication: 27 April 2017

MS 348-205 
Figure F1. A. Regional location map showing Site C0002 in context of the NanTroSEIZE project sites (according to Strasser et al., 2014). $\mathrm{TB}=$ Tosa Basin, $\mathrm{MB}=$ Muroto Basin, $\mathrm{KB}=$ Kumano Basin. $\mathrm{Box}=$ region with 3-D seismic data, red $=$ Expedition 338 sites, blue $=$ NanTroSEIZE Stage 1 and Stage 2 sites, yellow arrows = estimated farfield vectors between Philippine Sea plate and Japan (Seno et al., 1993; Heki, 2007), stars = locations of 1944 and 1946 tsunamigenic earthquakes. B. Schematic cross-section of Nankai accretionary prism, based on Moore et al. (2015).

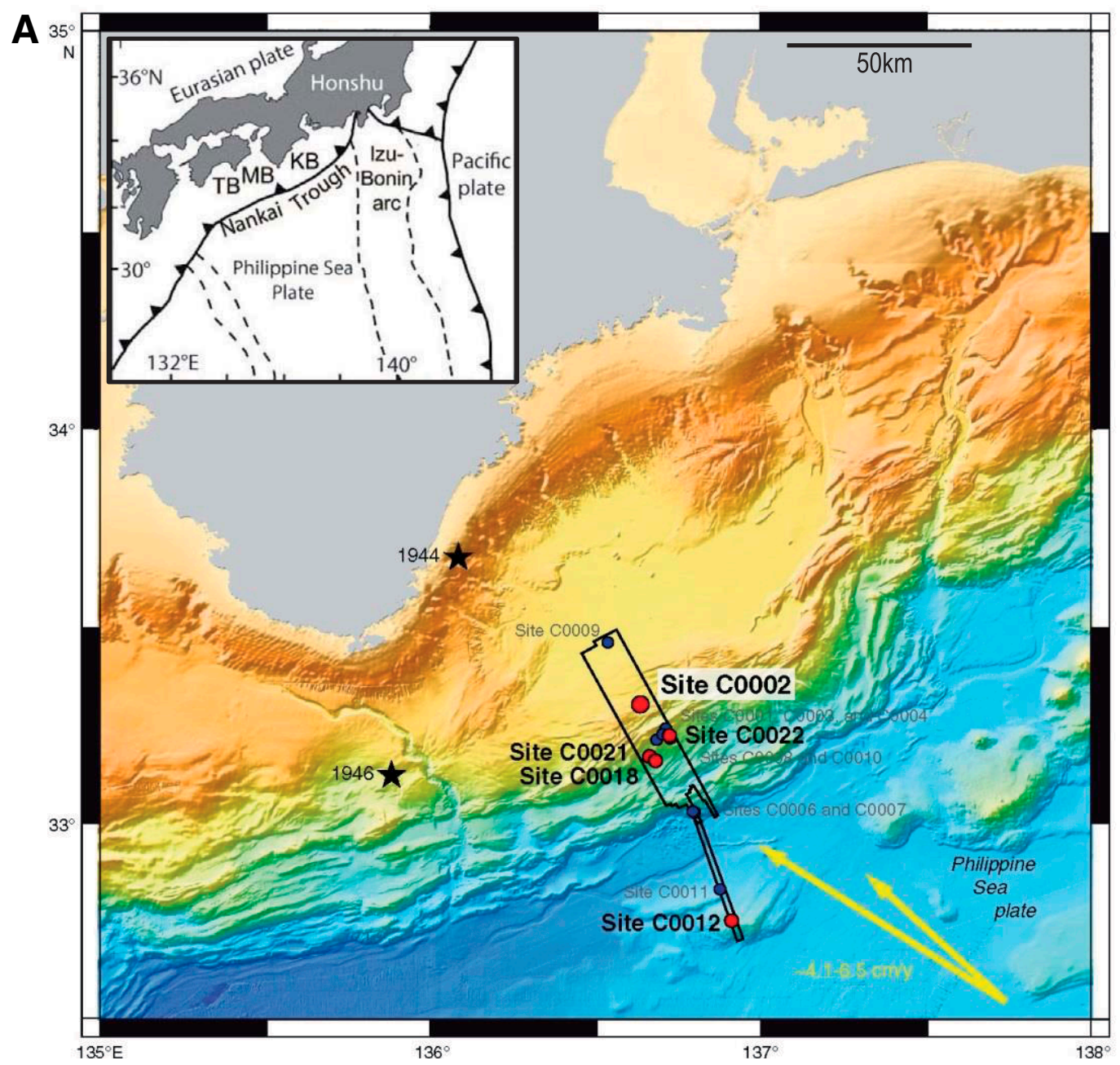

B

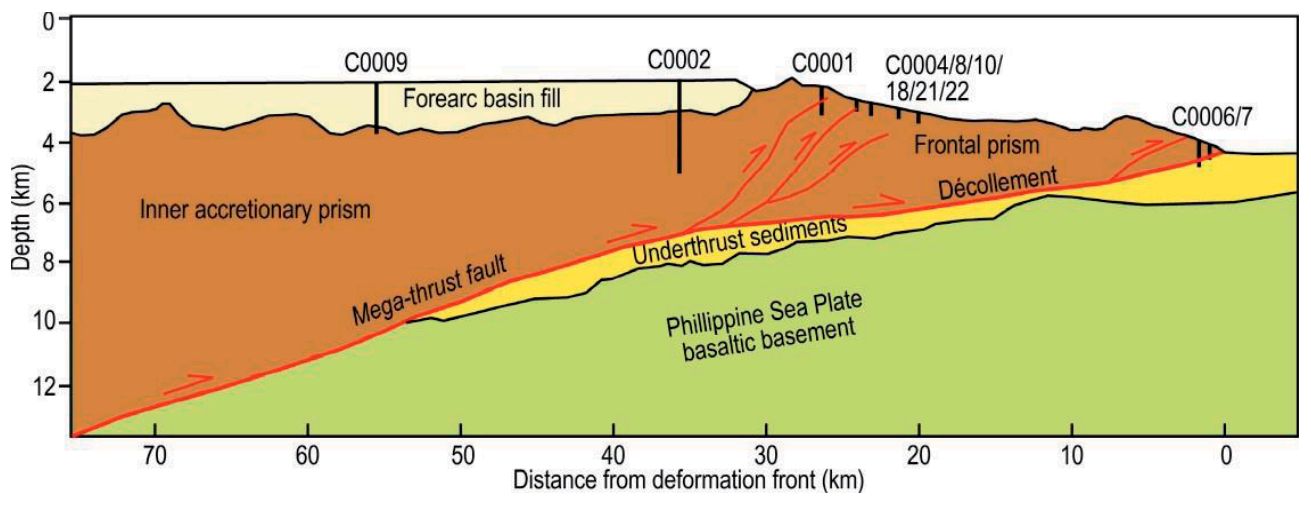


Figure F2. Photographs of Section 348-C0002P-5R-4. A. Archive half. B, C. Surfaces of slab made for thin section preparation (made on $\mathrm{C}$ surface). Square brackets = locations of drilling damage planes, rectangles = locations of Figure F3 photographs, bars and arrows to the left = orientation of cataclastic foliation in each piece of the core and shear sense along microfaults.

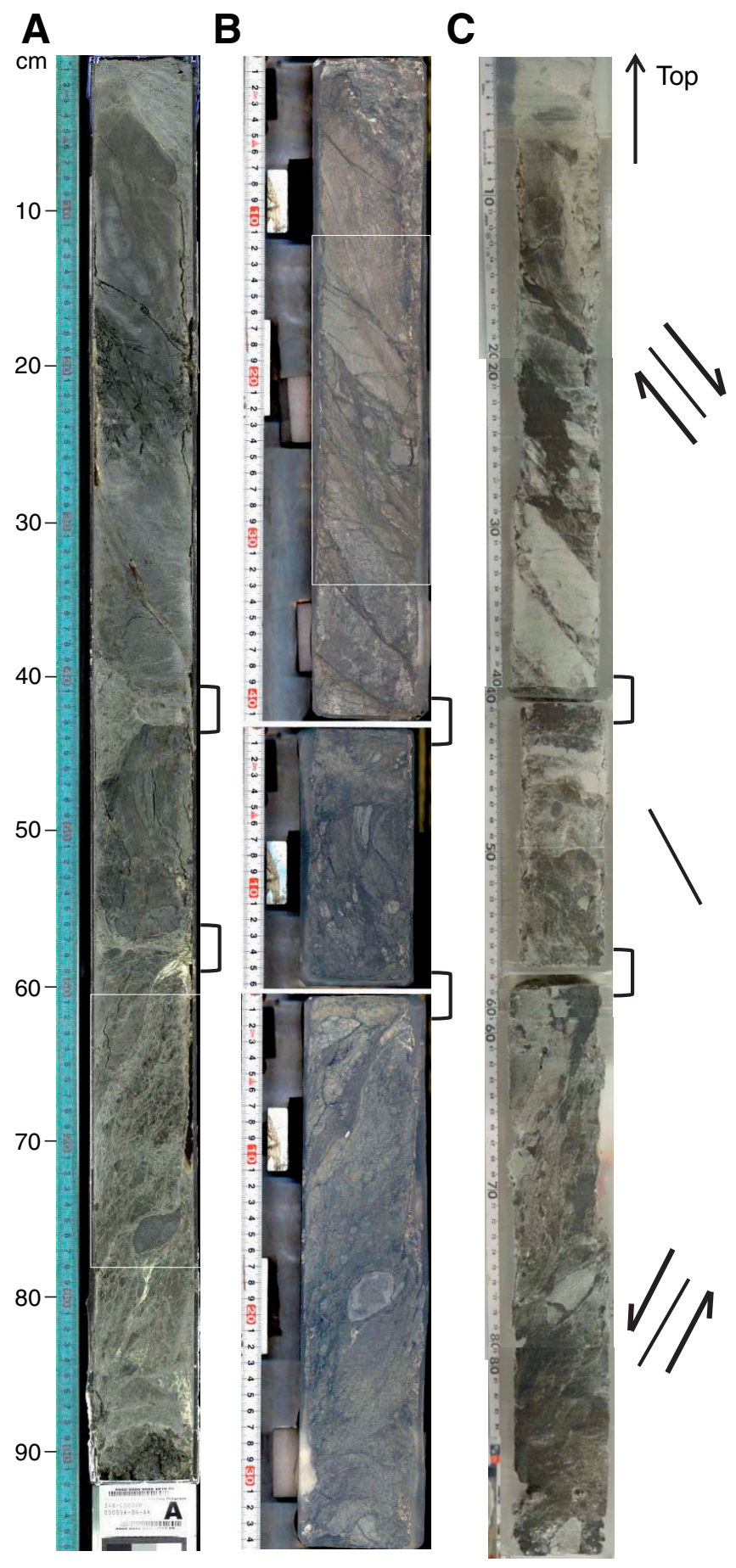


Figure F3. Photographs of Section 5R-4. Core top is to the left. A. Detail of archive half (Fig. F2A). B. Detail of slab corresponding to Figure F2B. Rectangle = domino-like structure, arrows = shear sense along microfaults. C. Locations of thin sections on surface of slab (Fig. F2C) and calcite veins (smaller rectangles).

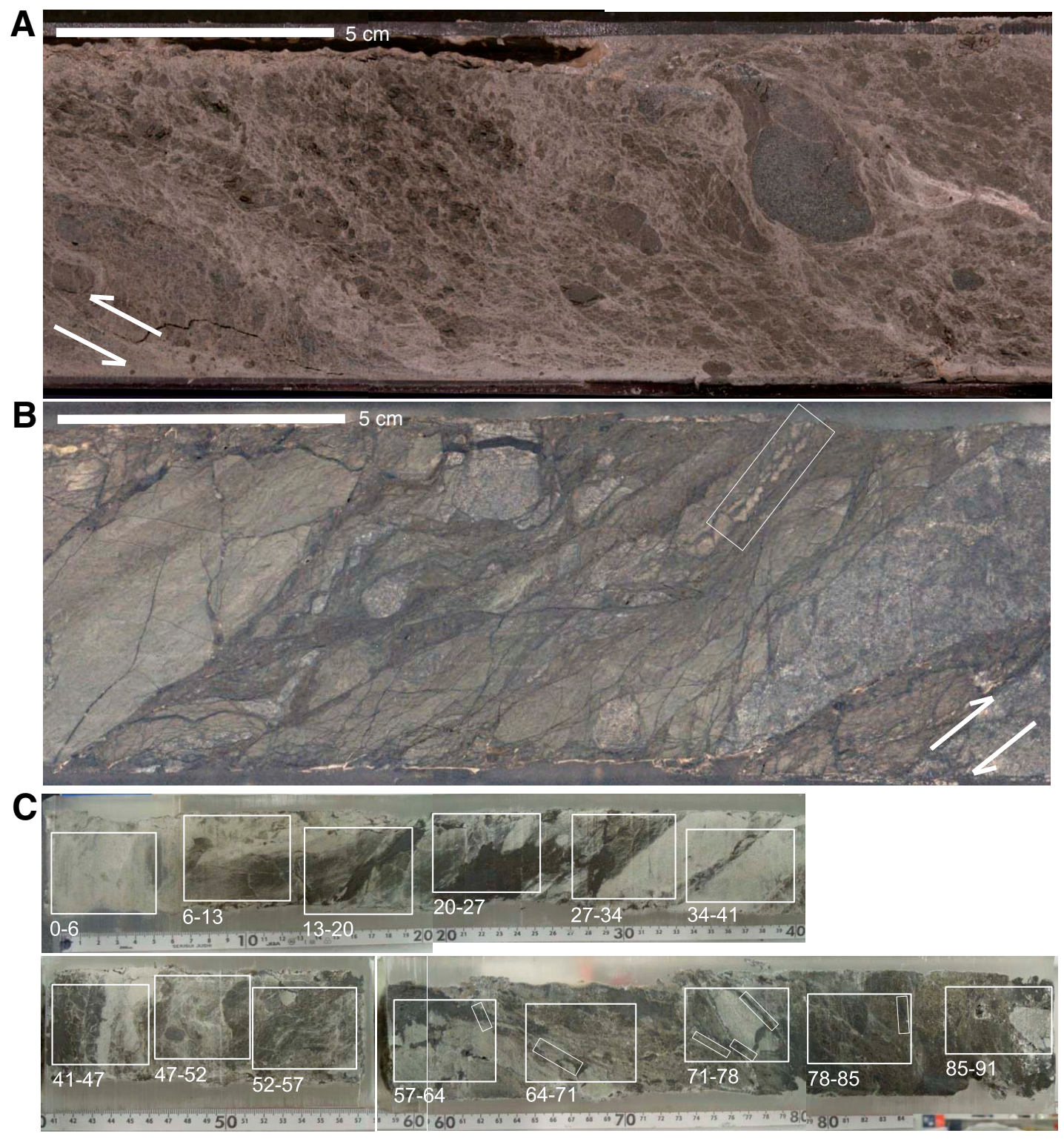


Figure F4. Photomicrographs of thin sections (TS) (open nicols). A. Sandstone and silty claystone (TS 06-13). B. Sandstone and silty claystone containing mud ball (TS 41-47). C. Sandstone (TS 06-13). D. Foraminifer in sandstone (TS 06-13). Arrow = direction of core top.

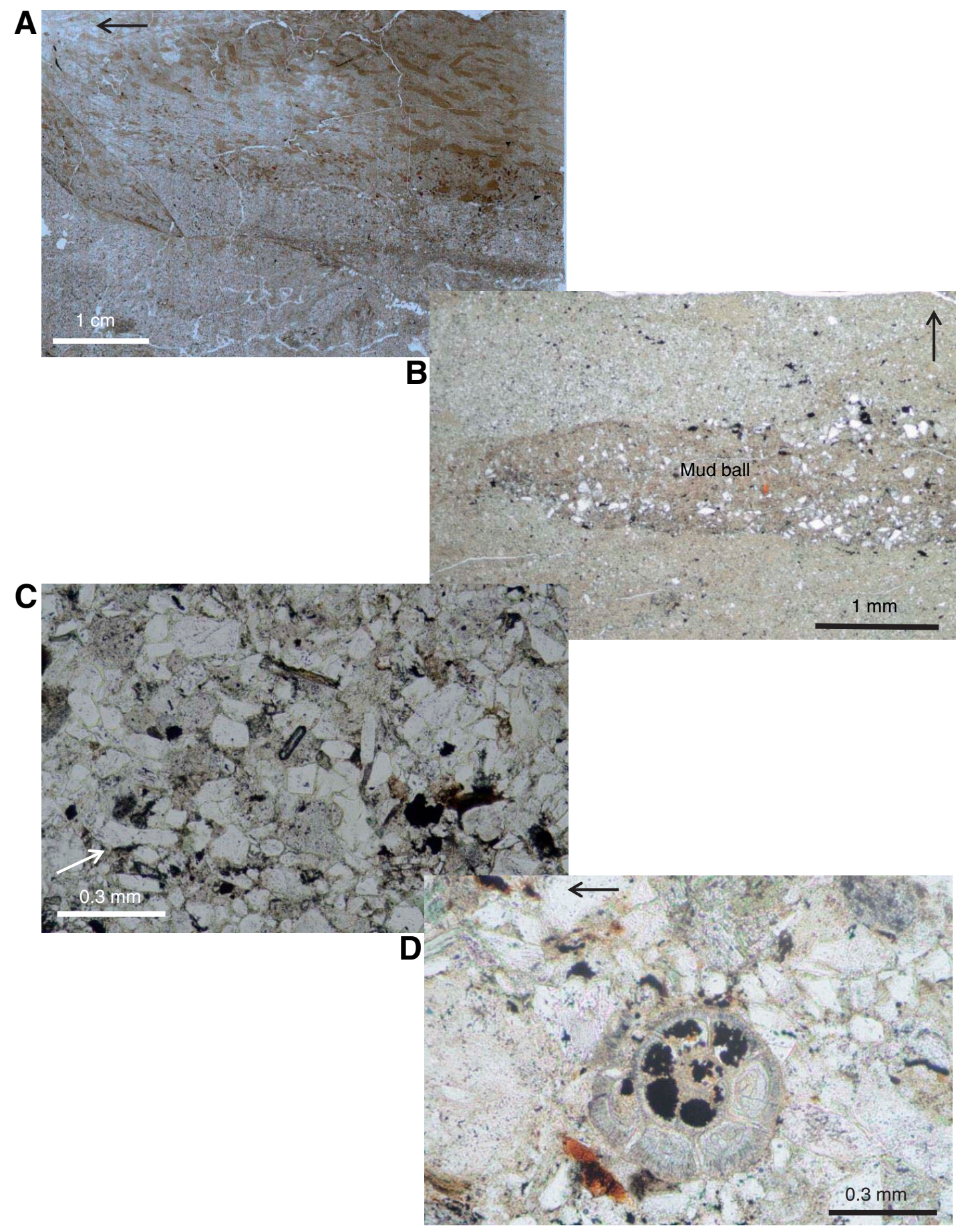


Figure F5. Photomicrographs of thin sections (TS). A. Lentil-type clasts composed of sandstone (TS 20-27, open nicols). Rectangle $=$ deflection of markers indicating shear sense. B. Lentil-type clasts composed of claystone (TS 64-71, open nicols). C. Anastomosing cataclastic foliation in silty claystone (TS 64-71, crossed nicols). Arrow $=$ direction of core top.

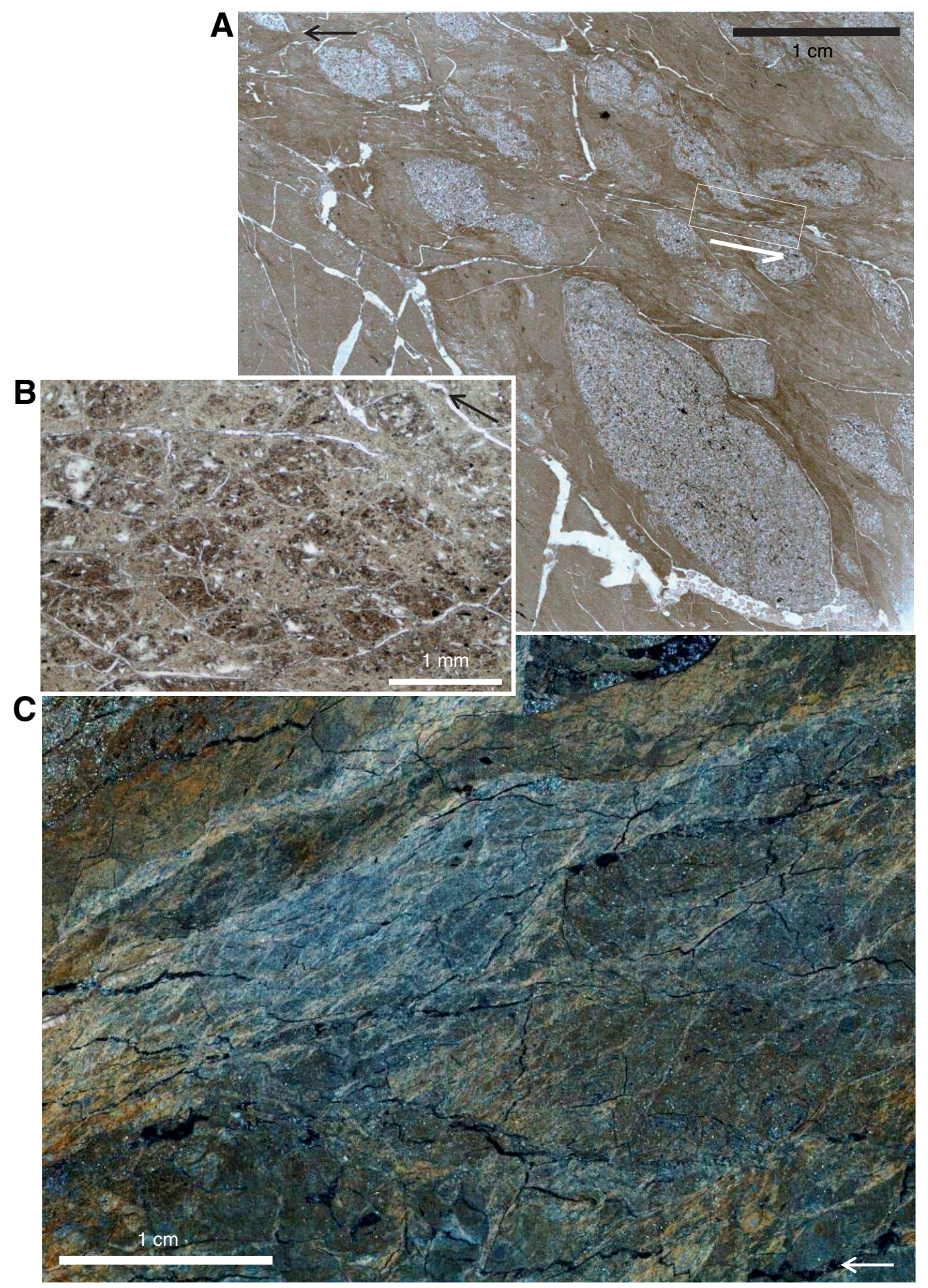


Figure F6. Photomicrograph of thin section TS 78-85 (crossed nicols). Note the preferred orientation of clayey minerals along surfaces that draw the cataclastic foliation. Arrow $=$ direction of core top.

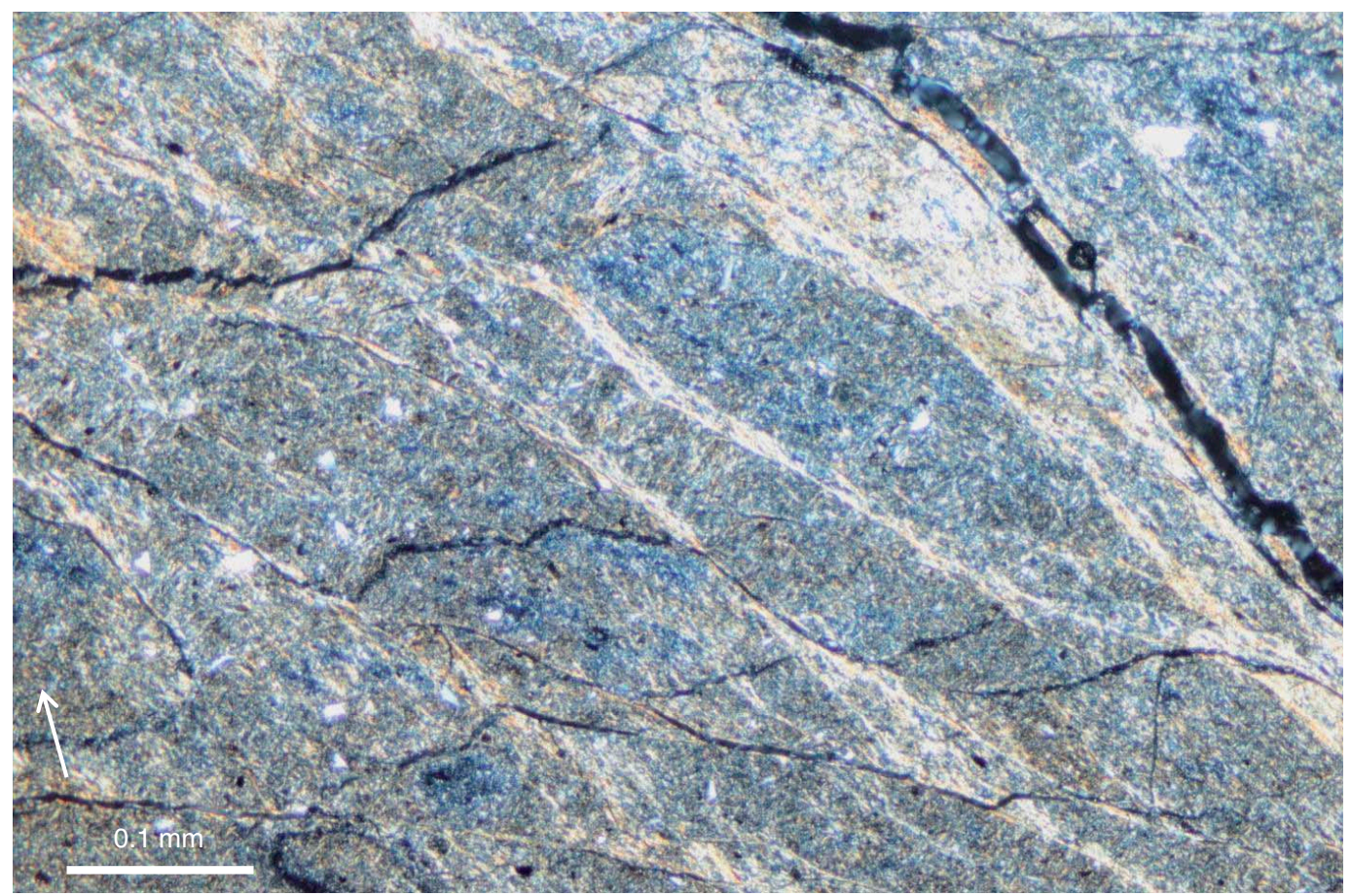


Figure F7. Photomicrographs of thin section TS 34-41 (open nicols). A. Microfaults along a sandstone/claystone boundary. B. Detail of A (rectangle). C. Microfaults cutting a sandstone/claystone boundary. D. Detail of $\mathrm{C}$ (rectangles). White arrow $=$ shear sense along microfaults, black arrow $=$ direction of core top.

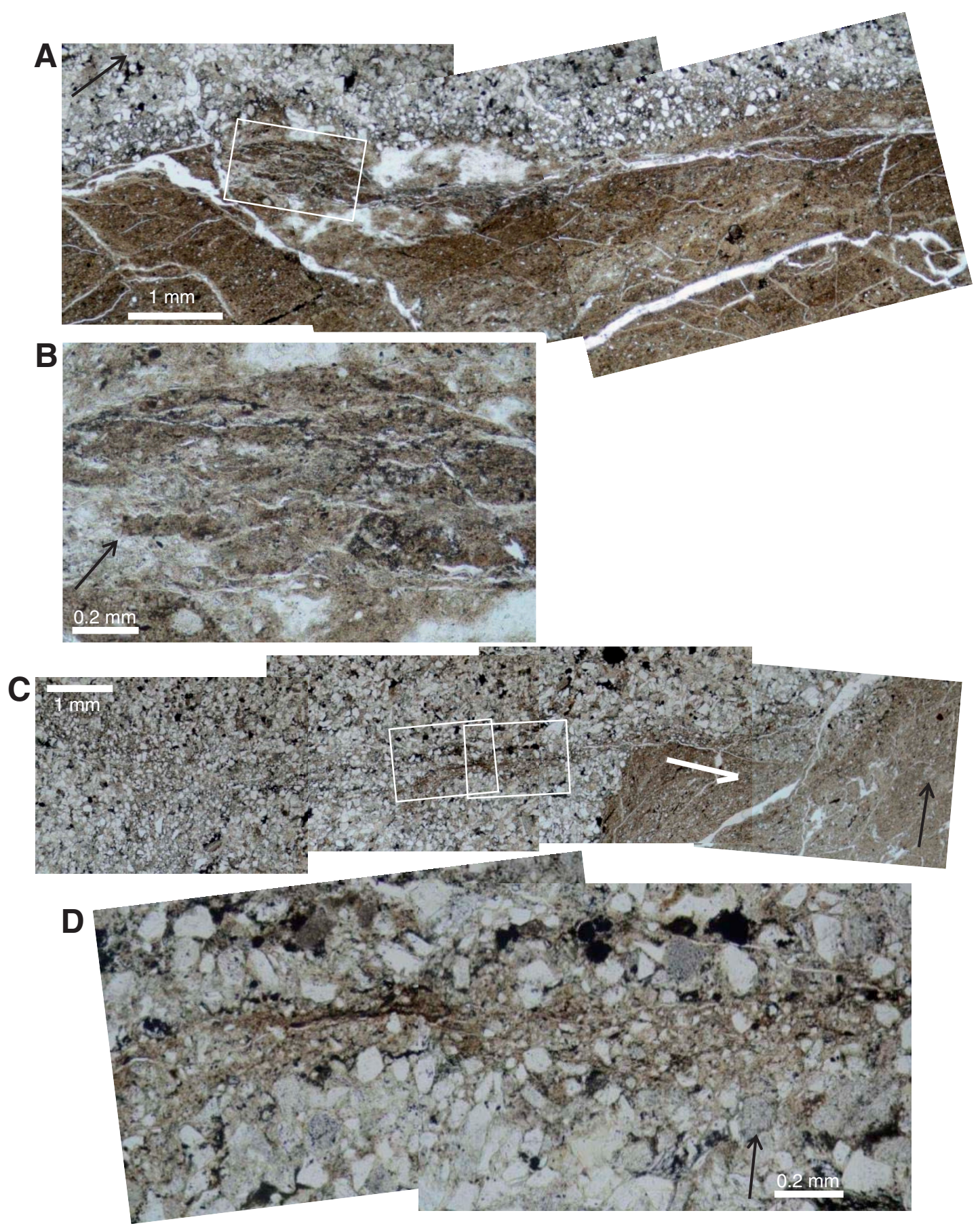


Figure F8. Photomicrographs of thin sections (TS). A. Drag fold marked by a previous microfault plane (TS 5257, open nicols). B. Drag fold marked by fragments of a fossil (TS 27-34). C. Detail of B (rectangle). White arrow $=$ shear sense along microfaults, black arrow $=$ direction of core top.

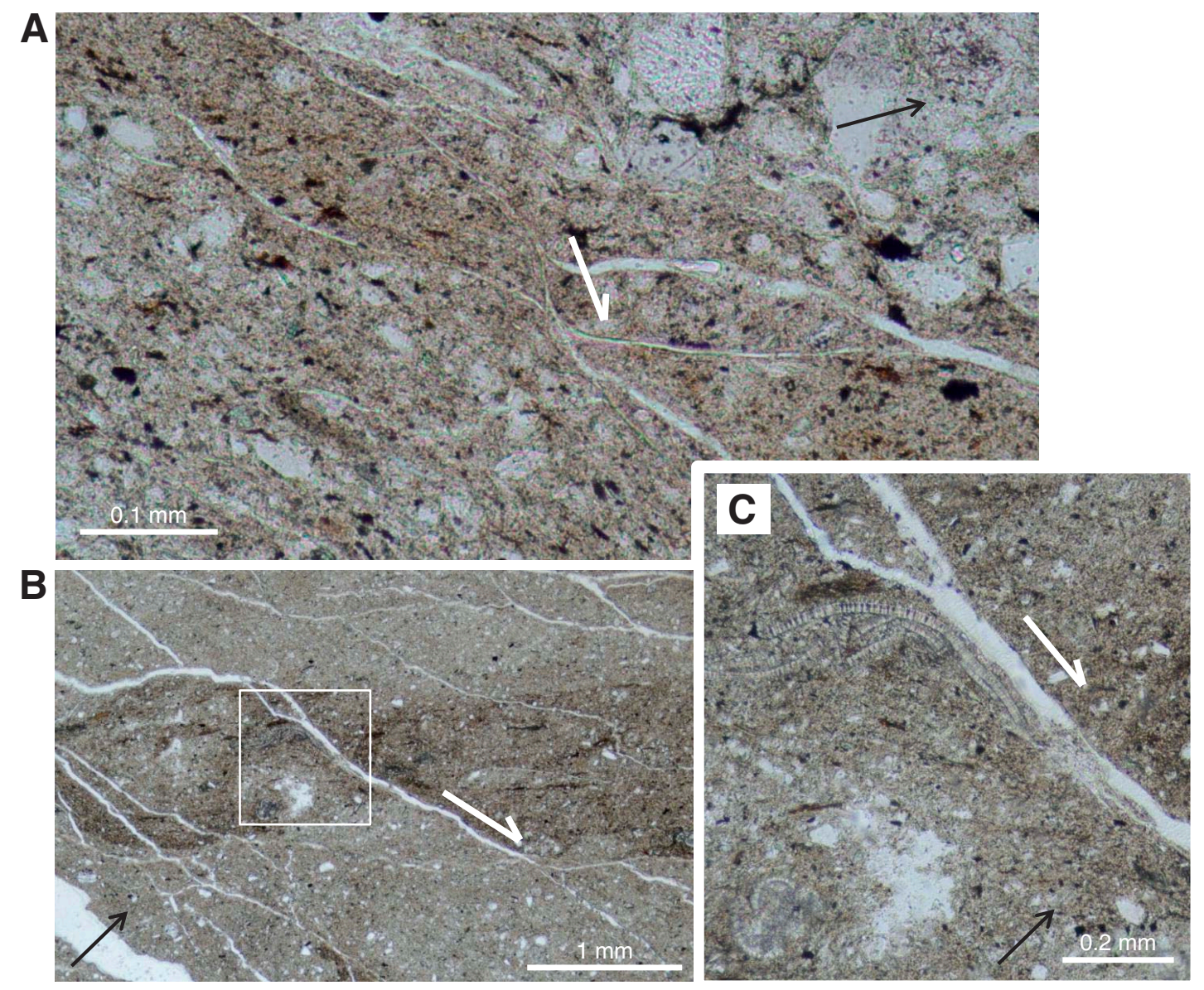


Figure F9. Photomicrographs of thin sections (TS) (open nicols). A. Array of microfaults cutting a layer of claystone intercalated between sandstone (TS 64-71). B. Normal microfault marked by a layer of opaque (TS 2734). White arrow $=$ movement along microfaults, black arrow $=$ direction of core top.

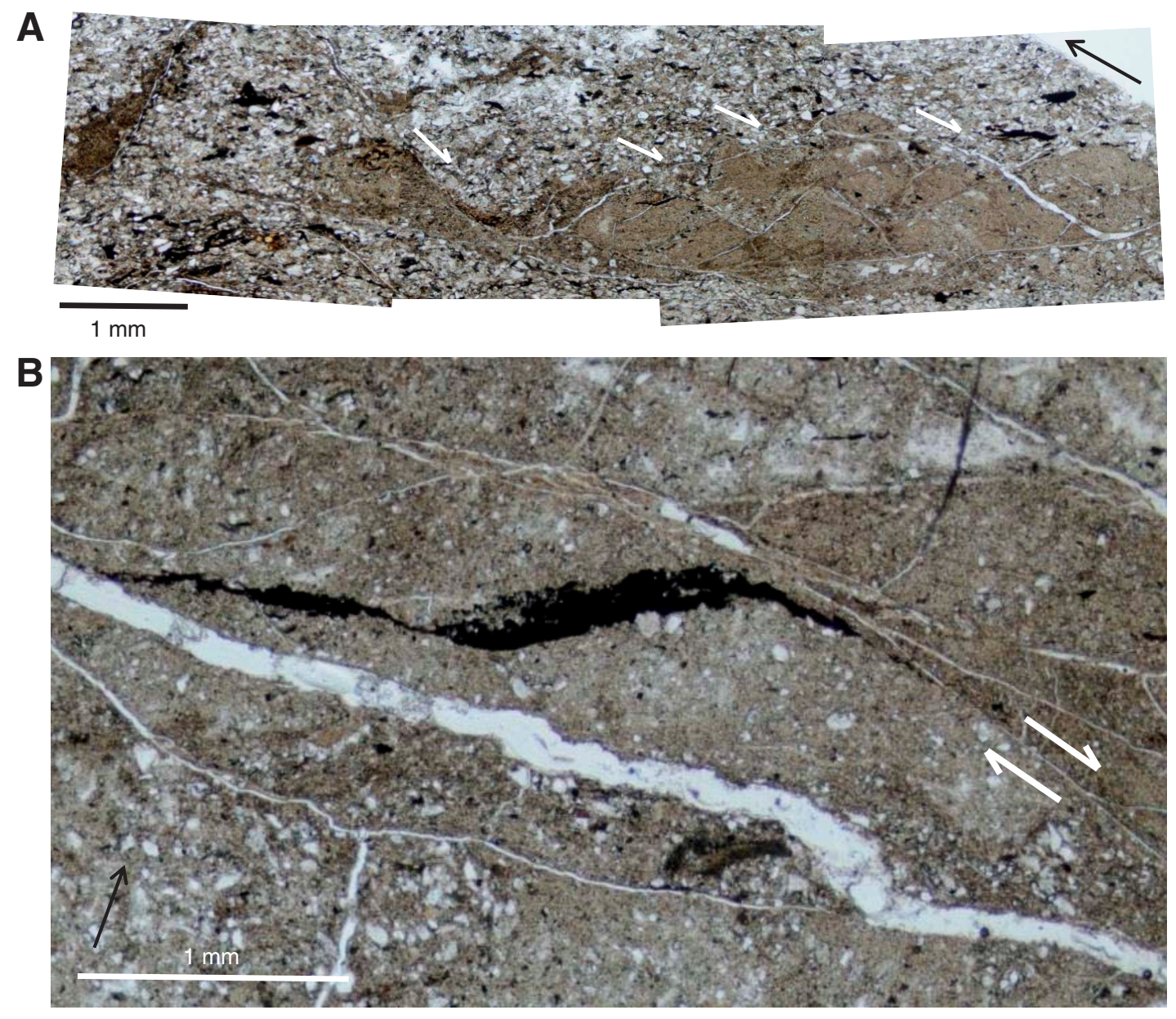


Figure F10. Photomicrograph of thin section TS 71-78 (open nicols) with a vein formed of aggregates of small calcite grains. Rectangles = details shown in Figure F11, white line = cataclastic foliation (mean orientation), arrow $=$ direction of core top.

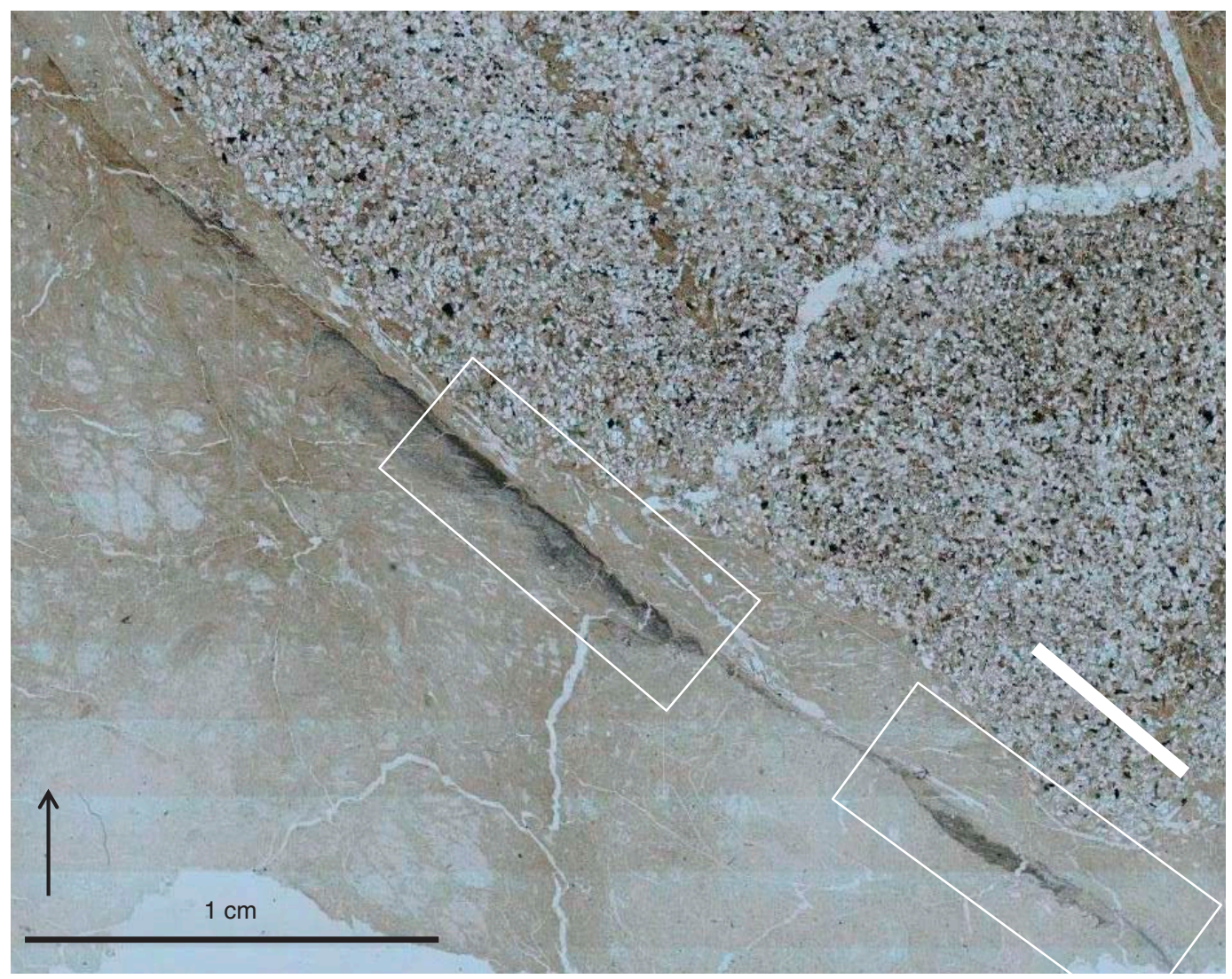


Figure F11. Photomicrographs of a vein formed of aggregates of small calcite grains (thin section TS 71-78, open nicols). A, B. Details of right and left rectangles in Figure F10, respectively. C. Sigmoidal shape of calcite grain aggregates (detail of A). D. Vein cut by conjugated normal microfaults (detail of B). White arrow = movement along microfaults, black arrow = direction of core top.

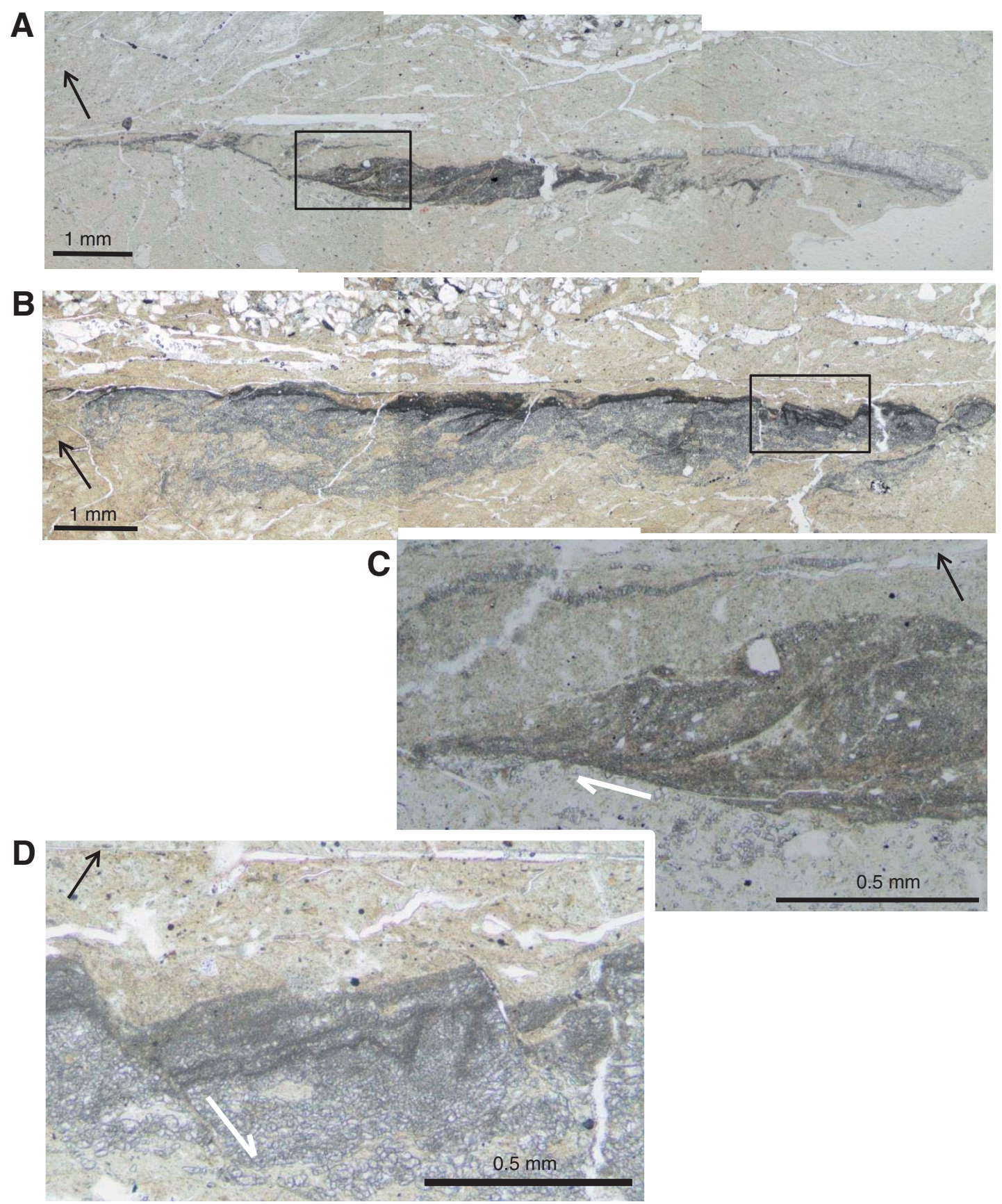


Figure F12. Photomicrographs of veins formed of aggregates of small calcite grains. A, B. Lentil-shaped aggregates (thins section TS 64-71, open nicols). Rectangle = location of B. C, D. Aggregates of calcite grains drawing the cataclastic foliation (thin section TS 71-78, open nicols). Rectangle $=$ location of D. White arrow = movement along microfaults, black arrow = direction of core top.

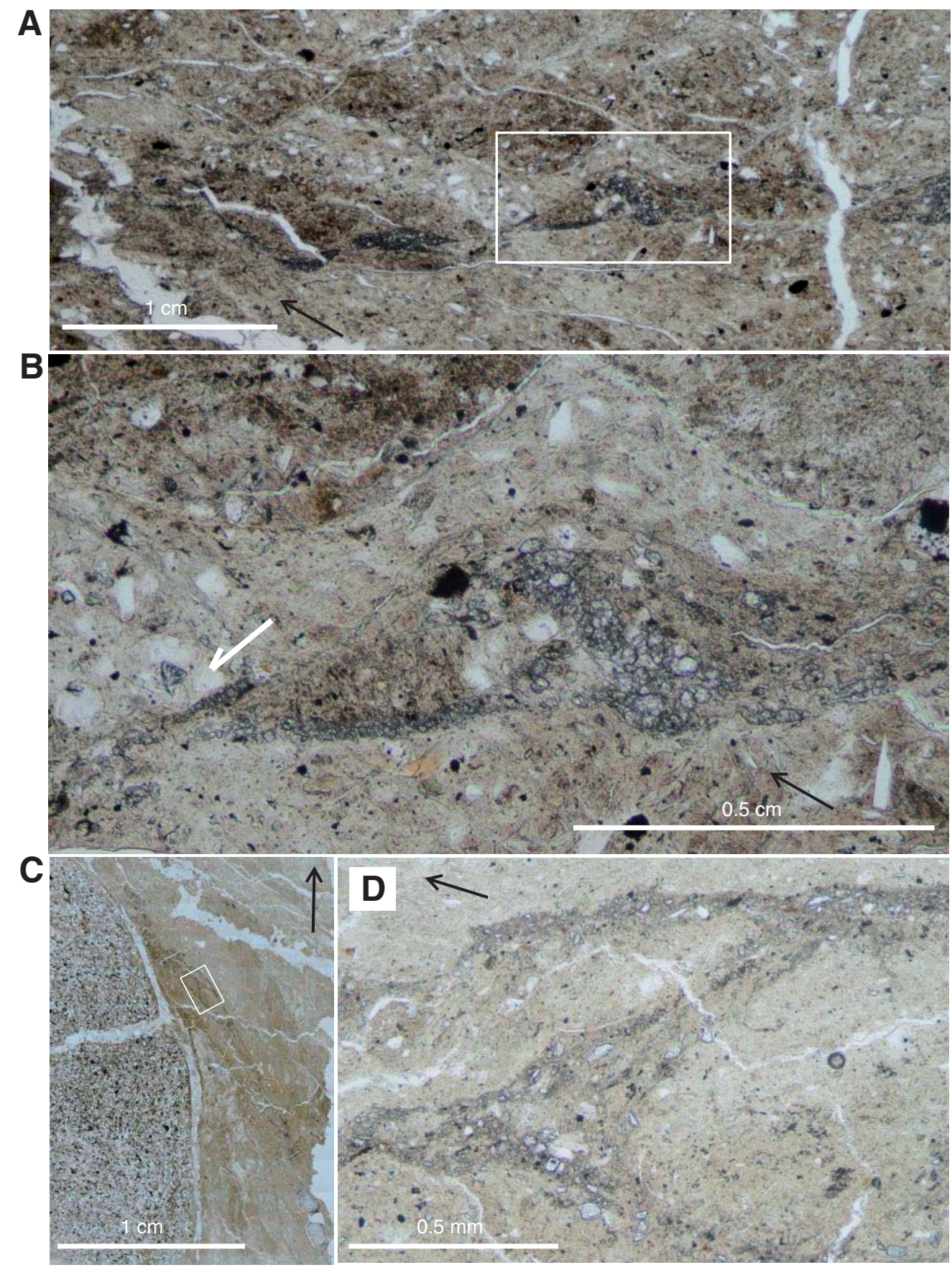


Figure F13. Photomicrographs of a vein formed of swarms of veinlets. A. Thin section TS 64-71 (open nicols). B. Thin section TS 78-85 (open nicols). C, D. Details of B (rectangles). Arrow = direction of core top.

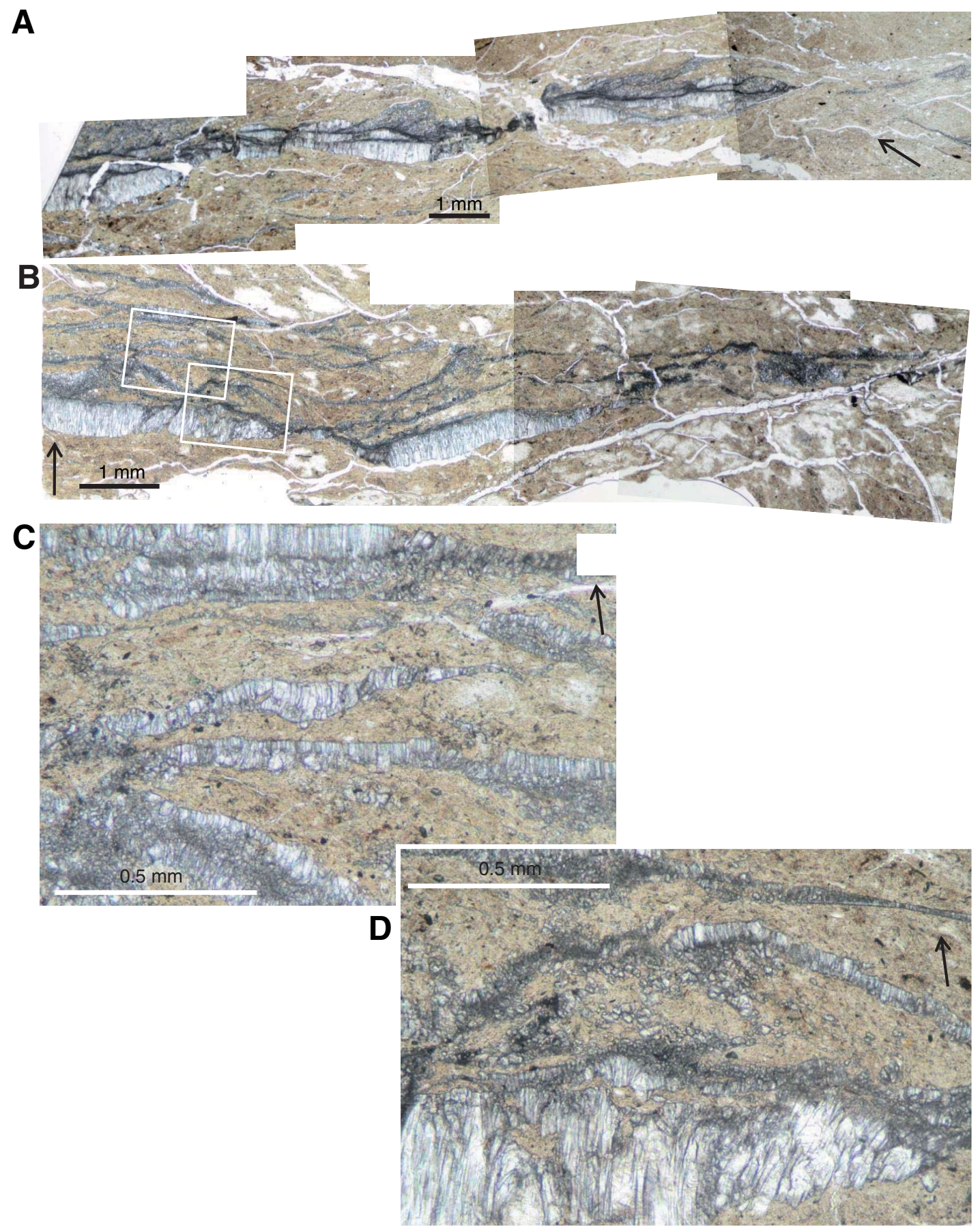


Figure F14. Photomicrographs of veinlets with a rhombic geometry. A. Thin section TS 71-78 (open nicols). B. Thin section TS 71-78 (open nicols). C. Detail of A (rectangle), with crossed nicols. Arrow = direction of core top.
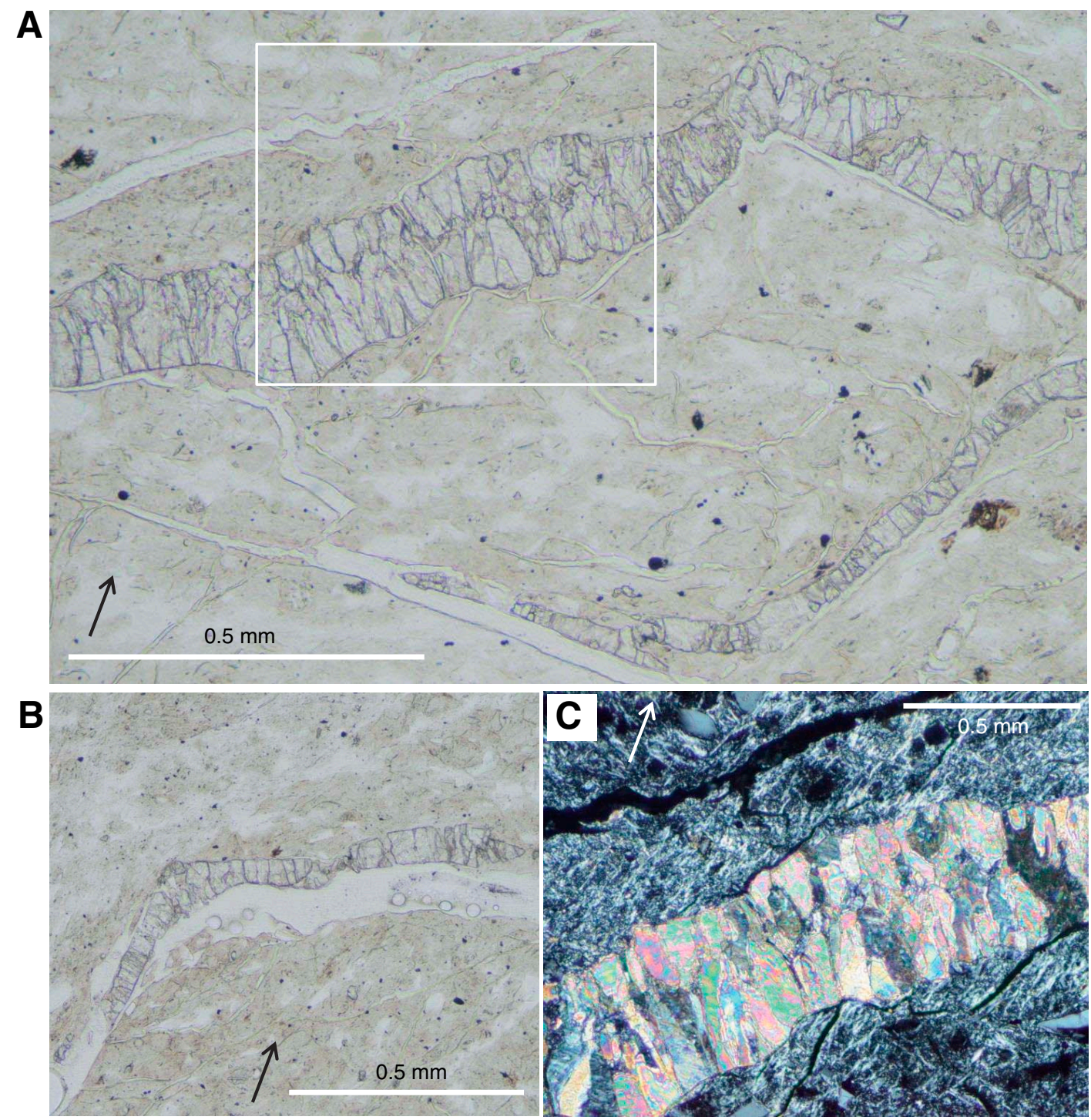
Figure F15. Photomicrographs of veinlets sealing cataclastic deformation. A. Thin section TS 71-78 (open nicols). B. Detail of left rectangle in A. C. Thin section TS 78-85 (open nicols). D. Detail of right rectangle in A (crossed nicols). Arrow $=$ direction of core top.

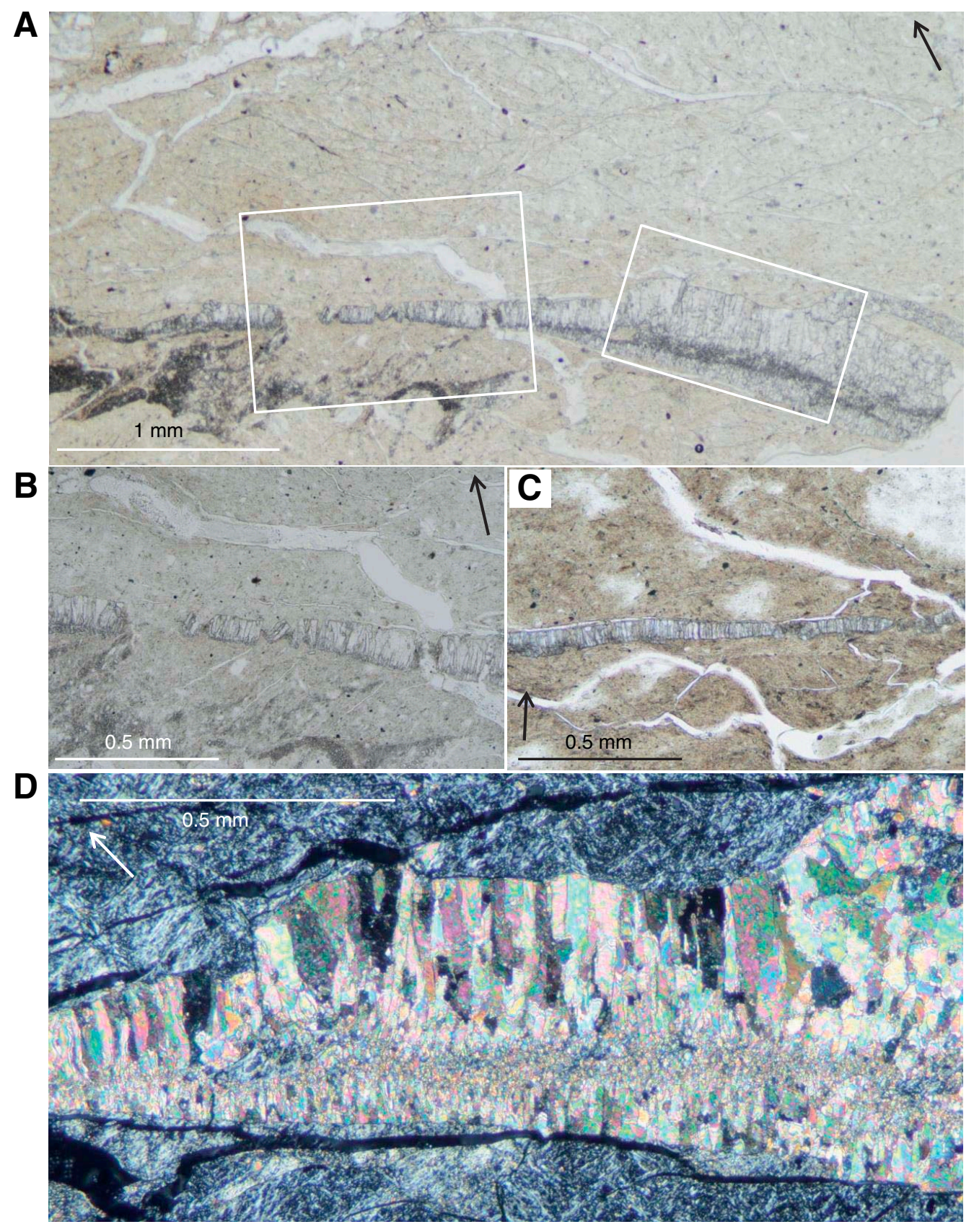


Figure F16. A, B. Photomicrographs of a microfault cutting a veinlet (thin section TS 71-78, open and crossed nicols, respectively). C, D. Photographs of wall rock inclusion bands and elongated calcite grains with broadening of grains toward the right (thin section TS 64-71, open and crossed nicols, respectively). Arrow $=$ direction of core top.

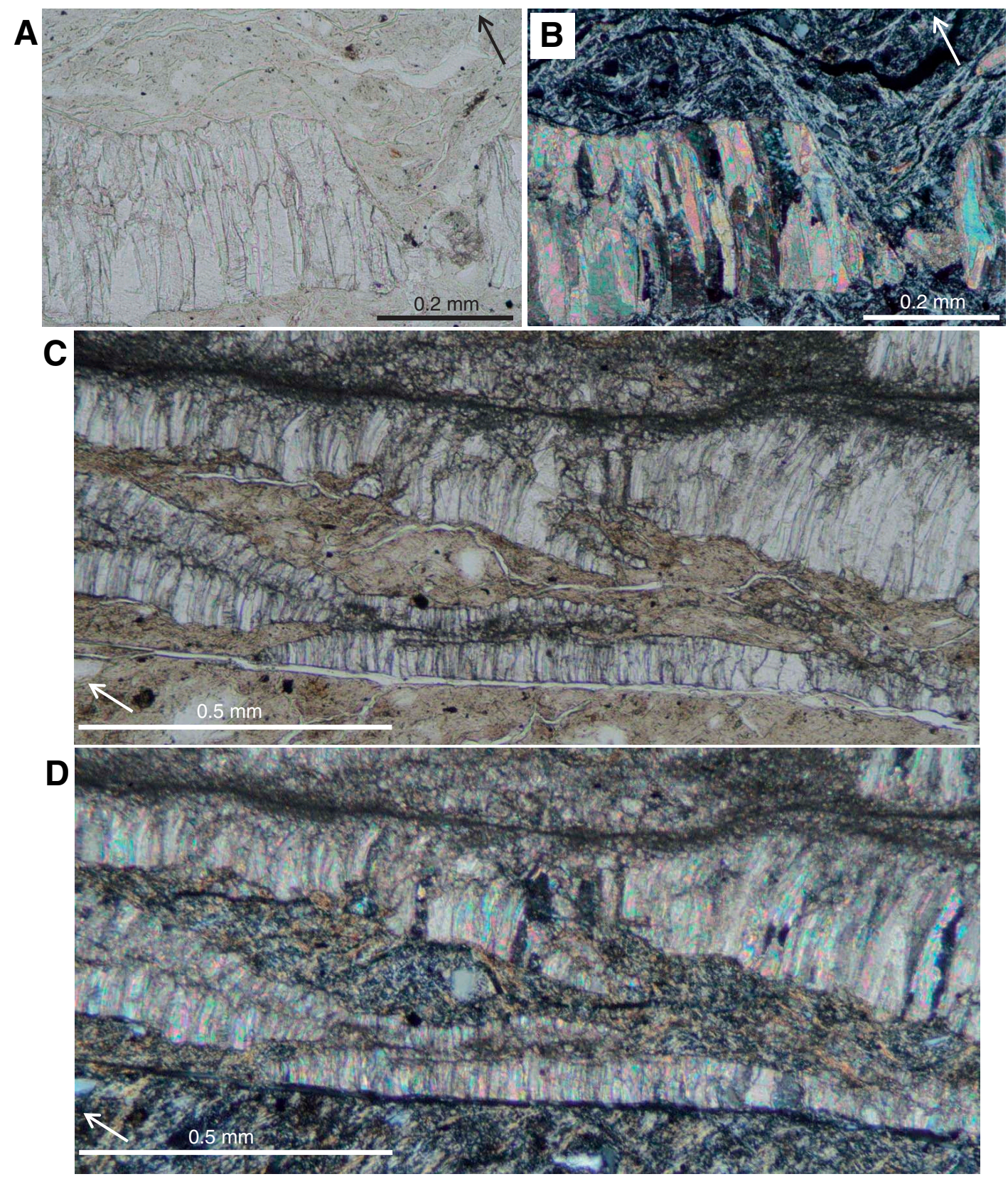


Figure F17. Photomicrographs of elongated calcite grains and wall rock inclusion bands. A. Thin section TS 7885. B, C. Thin section TS 71-78 (open and crossed nicols, respectively). D, E. Thin section TS 64-71 (open and crossed nicols, respectively). Note the very fine lines, interpreted as inclusion bands (circle). Arrow $=$ direction of core top.

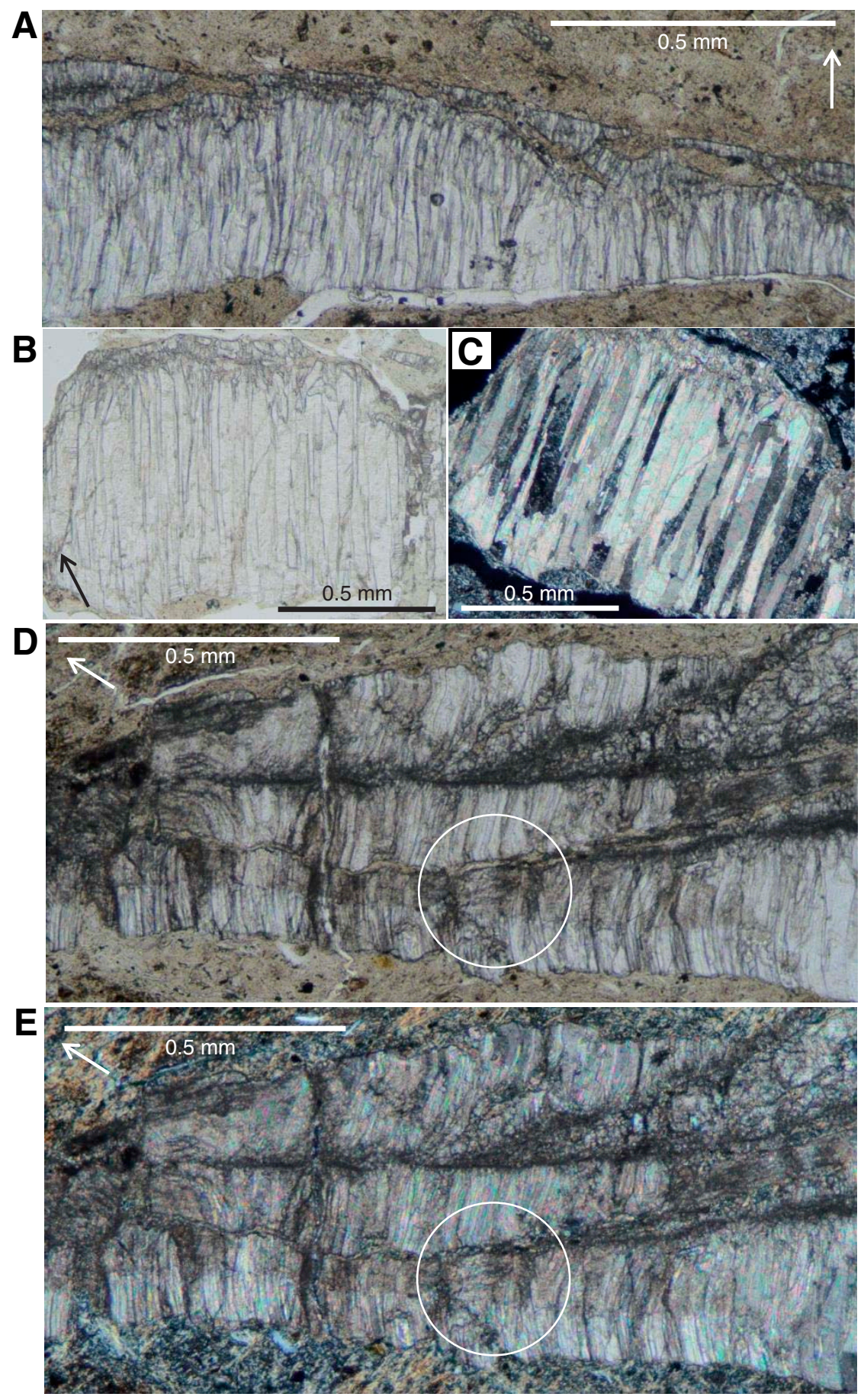


Figure F18. Summary of deformation structures, vein geometry, and their apparent orientation in fault zone drilled in Hole C0002P (Section 5R-4). Structure orientation: four rectangles correspond to thin sections (numbers indicated) and opening direction of veins.

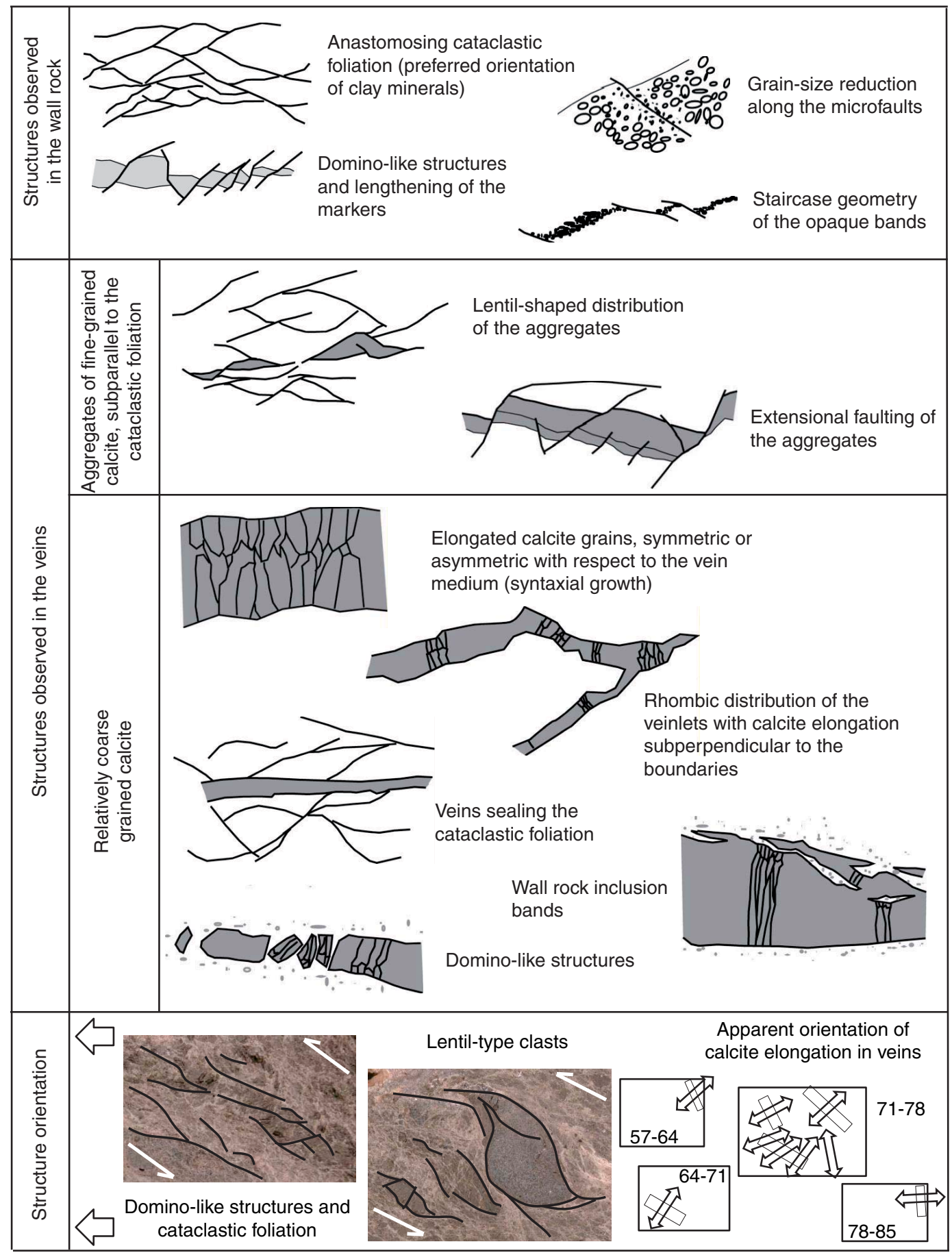

